\title{
My father's daughter: becoming a 'real' anthropologist among the Ubang of Southeast Nigeria
}

\author{
By Chi-Chi Undie (African Population and Health Research Center, Nairobi)
}

\begin{abstract}
This article explores some of the complexities of fieldwork for ethnographers conducting research in the ethnographic settings of significant 'others'. The fieldwork in question took place in the rural, geographically isolated community of Ubang, in Obudu, Nigeria, where I was following in the footsteps of my anthropologist father. Drawing on personal experience, I attempt to candidly examine the challenges inevitably faced in this situation, including acceptance by the community as a bona fide researcher, pressure to fulfill the expectations of others familiar with my father's work, and the struggle to carve out a professional identity distinct from my father's.
\end{abstract}

\section{Introduction: the Igbo, my father, and I}

As an eager (albeit apprehensive) doctoral student of Language, Literacy and Culture at the University of Maryland, I decided to carry out fieldwork within my own country, Nigeria, in 2001. I was excited by the prospect of exploring gender and power issues within Ubang, a little-known rural community within the wider local government area of Obudu, in the southeastern state of Cross River, one in which men and women maintain separate speech varieties. My exact location as the proverbial 'culture-bearer' (or 'indigenous ethnographer') is complex, however, for although I am Nigerian, and am indeed from southeastern Nigeria, I am not an Ubang indigene. I am, in fact, an Igbo woman, born of Igbo parents in Illinois, USA. I spent the first nine years of my life in Champaign, Illinois, and was raised for the next 14 years in Cross River State, Nigeria. I have strong emotional ties to the region and, in many ways, regard Calabar, the city I was raised in, as more of my home than my actual village. Although I identify as Igbo, I have never lived in Igboland (apart from a year in Nsukka at the age of four). Igbo was not my first language, nor was it the medium of communication in my home as I grew upEnglish was. I picked up the Igbo language later in life from friends and relatives, driven by a sheer desire to learn. For good reason then, when in the midst of my own people, I am usually initially considered a non-Nigerian, a non-Igbo Nigerian, or perceived as 'not $100 \%$ Igbo'. (For accounts of other anthropologists who have written on similar issues, see, for example, Abu-Lughod 1987 and Achebe 2002).

To make matters even more complex, my father is a professor of anthropology whose book, The Igbo of Southeast Nigeria (Uchendu 1965), has been credited with 'introducing Igbo society and culture to the world' (Osuji 1995:7). He is also considered by many as a very traditional Igbo man, who holds several chieftaincy titles and is highly regarded by his patrilineage. I have never asked why my siblings and I were not deliberately taught the Igbo language (a contradiction of sorts, considering my father's reputation for being 
'traditional'), but always assumed my parents thought we would pick it up soon enough once we returned to Nigeria. Given my background and chosen research site, one might be inclined to think (as I did) that carrying out an anthropological study 'at home' would pose few challenges. I was soon to discover my own naiveté.

Every researcher, as culture-bearer, encounters problems in the course of research. One such problem, as my father has indicated (Uchendu 1965), is the tendency to be so selective that the researcher omits that which s/he regards as obvious in the culture concerned, thereby robbing others of information that might be pertinent to a deeper understanding of that culture. He goes on to point out that this problem is not uncommon, for 'all ethnographers play an editorial role that involves some degree of data selection' (ibid:10). The emotional involvement and subjective framing one has with one's own culture may also pose reporting problems. My father attests to the relevance of this emotional involvement to social science. He writes: 'It guides the reader in his assessment of the writer, and, methodologically, it can help us to determine the degree of objectivity (when we know how) with which social scientists in general approach sensitive topics in other areas of human behavior' (ibid).

I share with my father a recognition of the importance of an emotional relation to the people I worked with in my fieldsite, and yet, also, a contradictory need to be objective. Where my father is concerned, this is more understandable - since the 'Writing Culture' debate (cf. Clifford and Marcus 1986) was yet to happen at the time of his fieldwork among the Igbo, and it was the rule, rather than the exception, that anthropology was thought to be a science in the same way as the natural sciences. My own need to be 'objective', on the other hand, perhaps had more to do with the 'violence' of the ethnographic eye and the tension between being an insider and an anthropologist at the same time. My emotional involvement - my husband's relation to the Obudu community, for instance-led to tensions that shaped my research. It gave me a feeling of responsibility in the representation of the Ubang. I felt a deep need to protect my study community from the very personal intrusion that ethnographic writing can become. Perhaps, paradoxically, my emotional involvement drove my need to be 'objective'-for instance, I was careful not to get involved in any conflicts, cautious about making onesided representations in case studies, wary about uncritically accepting my husband's interpretations of cultural phenomena, etc. 'Objectivity' is plausibly something to hide behind for those like me who happen to be doing research 'at home.' Relatives and others invariably had expectations of my research, which were diverse and difficult to meet. My claim of objectivity could arguably be a means of dealing with such pressures and personal agendas.

Finally, when working within a culture of one's own country, one also struggles with the issue of which and how much data one can use and still remain 'loyal' to a context of which one is a part. For instance, do I describe the Ikwong secret society in terms as ominous as those used by the Ubang themselves - or do I 'tone it down' a little? Do I divulge details about the love lives of elderly, female respondents during the time of their youth, or would that be unseemly, considering their present-day respectability and positions in the church? These were the kinds of issues I struggled with subconsciously.

In 1965, my father observed: 'Objectivity is the aim of our science. Every ethnographic writer tries to attain it' (Uchendu 1965:10). Today, in 2006, most anthropologists would 
argue that unbiased research is an overly-ambitious goal, at best. Shaped by my emotional attachment to the general Obudu community, I wondered how I would be able to approach this research project 'objectively'. I wished to strive for a balance between a respectful portrayal of the Ubang, and as impartial a perspective as possible on the gathered data. In fact, despite the complexity of my own positionality (as perhaps a 'quasi' bearer of Ubang culture), the struggles of doing anthropology 'at home' described above formed an integral part of my research experience, including the problematic issues of selectivity, 'objectivity', and loyalty. However, contrary to my father's treatment of emotional involvement as a potential impediment, I prefer to view the same as accruing colossal benefits to the research endeavor: it guides the researcher in pursuing key issues.

In this paper, I wish to argue that my experience with emotional involvement in the Ubang community, rather than being a mere device for the critical assessment of my 'objectivity' level, is instead reminiscent of Elliston's description of this phenomenon as 'foundational in creating ethnographic knowledge about other cultural worlds' (2005:30). Citing Newton (1993), Elliston notes that
the medium of emotion 'empowers me in my projects and, when it is reciprocated, helps motivate informants to put up with my questions and intrusions' [Newton 1993:251]. Here Newton raises questions anthropologists rarely pose: Why do our research subjects tolerate us? How do we manage to plug away at fieldwork for months and years in what are oftentimes unfamiliar and stressful social contexts? (Elliston 2005:30, original emphasis)

Newton's words illustrate my experience amongst the Ubang. Emotional involvement with my study community and the consequent reciprocity and motivation that Newton alludes to, proved to be major facilitators of my research encounter with the Ubang, granting both me and my informants the 'staying power' required to see the project through.

\section{How to enter a Nigerian village as a 'not-yet-real' anthropologist}

My choice of Ubang, Obudu as my study community did not stem from pragmatic considerations alone. The Ubang diglottic culture struck me as something that would be fascinating to try and unravel. In addition, I also felt it would be more interesting being an 'outsider' to a certain extent, given the unique challenges confronted by anthropologists who work 'at home', and the discipline's expectations that they work elsewhere.

My father taught at the University of Calabar, Nigeria, for nearly two decades. Fortunately for me, one of his former students, Mr Daniel Ochui, turned out to be the representative appointed by the Chief of Ubang to handle all inquiries about the Ubang village. This individual, a graduate of sociology, became a key informant for my study of Ubang culture and made my entry into the society much less complicated than it might have been.

It is important to note that although Calabar is the capital city of Cross River State, it is not part of the northern region where Ubang is situated. Again, I am fortunate in that I married into an Obudu family. Obudu, a part of northern Cross River State, is also the 
local government area (LGA) of which Ubang is a part. Many members of the Ubang community were already acquainted with my husband and his family. My husband's cousin, who graciously served as my videographer and driver, was also well-known in Ubang, being the first videographer (and the only one, for a long time) in Obudu, and visiting Ubang often, by invitation, to videotape various ceremonies.

In spite of the 'insider' advantages described above, my initial meeting with the Chief's representative, Mr Daniel Ochui, was not exactly hitch-free. I went to see him at his office outside Ubang in 1999. I was accompanied by my in-law, the videographer, who had arranged the meeting. Following introductions and a description of my research interests, I was told bluntly: 'Actually, we need someone like your father, who has written so many books, to come down here and do a study on the Ubang people.' Not to be deterred, I fought to ensure my expression remained impassive. I then assured $\mathrm{Mr}$ Ochui that my father was personally fascinated by what he had heard concerning Ubang's diglottic culture and was planning to accompany me during my initial two weeks of fieldwork the following year. This response seemed to satisfy him and so we parted, agreeing to meet again in May 2001.

As I recall, my father did promise to give me two weeks of his time once I was ready to commence my fieldwork. I naively took this to mean that I could relax and count on his expertise as an anthropologist who had done much work among rural peoples both within and beyond the African region. Upon my arrival in Nigeria in May 2001, however, I was stunned to learn he had only meant that he would be coming to Ubang to survey the place for the satisfaction of his own curiosity. He had no intention of 'helping' me with my research because he assumed that my training had already prepared me for that. And so I left for Ubang on my own, with my two-year old son in tow, and a promise from my father to arrive in a couple of weeks.

This promise was relayed to Mr Ochui, who happily shared the news that Prof. V.C. Uchendu would be coming soon with the Chief of Ubang and his cabinet. The Ubang people's excitement over an impending visit by a renowned anthropologist can be linked to the fact that the Ubang culture, unique as it is, is still little-known within Nigeria. The Ubang language also has no orthography. Educated Ubang indigenes have made several unsuccessful attempts to draw the attention of national and foreign linguistic experts to the region, in the hopes that the eventual extinction of their language would be prevented. This concern was expressed to me as well on a number of occasions, which may equally have facilitated my relatively easy entry into the community. Interestingly, therefore, the idea of 'a real anthropologist' coming to Ubang opened doors for me, serving as an icebreaker of sorts as far as Mr Ochui was concerned. From then on, we developed a relationship of mutual respect and intellectual engagement.

As it turned out, my father never made it to Ubang, due to various circumstances beyond his control. Nonetheless, his impending arrival could not have proven more useful in facilitating the research process. I convinced myself that his unavailability was a good thing. As a student enrolled in an interdisciplinary doctoral program, I often felt like a 'jack-of-all-trades' but 'master of none'. This was my chance to carve out a niche for myself in the fascinating field of anthropology. 


\section{The village council meeting: being a 'stranger' for the first time}

Mr Ochui ensured that my entry into the Ubang community was relatively uneventful. He set up the required meeting between me and the village council, ensuring that I did not 'come empty-handed', but brought along the necessary gifts to be presented as a sign of respect to the Chief and his cabinet. The gifts, which cost less than a total of $\$ 10$, included items such as a bottle of whisky, specifically for the Chief, seven seeds of kola nut, some bitter kola, a crate of soft drinks, and two gallons of palm wine.

As Mr Ochui began the elaborate process of introducing me formally to the village council, it slowly dawned on me that despite his kind assistance, there would be no easy waltzing in and out of the Ubang community. I became uncomfortably aware of my 'outsider' status in the context of this village council meeting. I was an Obudu wife, yes (and thus, paradoxically, an 'insider,' too), but a wife that spoke neither Bette ${ }^{1}$ nor Ubang, and one who had little knowledge of the etiquette required to address members of the council. I had to be told (via urgent whispers from Mr Ochui) when to stand up, how to politely refuse the kola nuts that were passed round (kola nuts had never particularly appealed to me), as well as when it was my turn to speak and describe my research interests. By the end of the village council meeting, I was publicly given permission to interview anyone about anything, with one exception: I was not to ask any questions about Ikwong, Ubang's frightening secret society, for that would be sure to create hostility and sabotage my research goals. The details about Ikwong were regarded as the 'secrets of the land' and, as an 'outsider', I was forbidden to delve into this particular subject. (One informant, who publicly cautioned me against this in the presence of the village council, later assured me in private that he would provide some peripheral information about this secret society, but that this could only be done outside the Ubang village.)

I was a stranger. Ironically, in those moments at the meeting, my researcher role seemed to have made me the stranger, my 'wife' status notwithstanding. I was going to have to break through the reserve of community members and gain their trust and respect. Afterwards, as I made my way down to a certain compound to get acquainted with some of the women in the community, a couple of youth called out derisively: 'Where's the donor's money?' The erroneous insinuation was that I must have received some sort of funding to carry out my research; thus, surely the community was entitled to a portion of it. Following my first discussion with some women that day, the leader of the Ubang women's government remarked in the local dialect as she passed by, 'Where's our kola?' By this, she referred to an expected small gift for women's participation in the research study. Such were the first couple of days of fieldwork, after which my presence in the community thankfully seemed to become unremarkable.

As a wife of the Obudu community, I cannot deny the discomfort I felt when some community members were suspicious of my presence. However, in an odd way, being

\footnotetext{
${ }^{1}$ Bette, a primary Obudu language, is universally spoken in Ubang as a second language. The Ubang clan has undergone a 'double colonisation' of sorts, for the Ubang language has no orthography. Educational materials are therefore written in Bette or English. Bette is the language used in schools and it is also the language of commerce. Consequently, the Bette language has attained something of a prestigious status in Ubang and is regarded as the more progressive language.
} 
marked out as a 'stranger' made me feel more like the anthropologist I was trying so hard to be. Still, I could not help but imagine, during those initial two days, how much easier it would have been to do this in my own natal village, where everyone knew who I wasor, at least, who my father was - and would understand why my Igbo was not flawless.

\section{Getting to 'know' the 'natives'}

My interviews with Ubang participants were carried out in New Jerusalem-Ubang, a section of the Ubang community with strong ties to the Assemblies of God Church. I soon became cognisant of the impact that location can have on the kind of data one is able to collect. Initially, I experienced quite a bit of resistance in the field to questions concerning old traditions that had either completely faded away, or were in the process of doing so. Informants were sometimes fearful that their detailed descriptions of old customs would reflect negatively on New Jerusalem's reputation as a Christian community. I constantly had to reassure them that my interest in these customs in no way affected my perception of them as religious Christian people.

During much of the time I spent at Ubang, I dressed very simply and had my hair done in the local 'tie-tie' hair-do embraced by many rural women. Although this was done more for the sake of convenience and comfort than as a strategy to make me 'fit in', in retrospect, I believe my plain appearance did play a part in making me seem approachable, and helped facilitate the formation of informal relationships between me and my collaborators. The fact that I was always accompanied by a known in-law also might have helped the Ubang people come to regard me as an 'Obudu wife' attending school in the USA, rather than as a complete 'Igbo stranger'.

How this must have differed from the fieldwork experience of my father, who, 40 years ago, returned to his natal village as a son already utterly accepted and respected, his positionality as an ethnographer plausibly invisible. It was, perhaps, this experience that led him to assert:

The 'native' point of view presented by a sympathetic foreign ethnologist who 'knows' his natives is not the same as the view presented by a native. Both views are legitimate, but the native's point of view is yet to enrich our discipline. The argument that a culture-bearer must be assigned only to the role of an 'educated informant' grows less and less persuasive. Many anthropologists acquire a crosscultural perspective through reading and participating in foreign cultures, that is, knowing more than one culture at firsthand. The latter should not be confused with 'living' more than one culture. Very few people are in a position to do this. Not even the celebrated ethnographer Malinowski could be credited with this: his stay of two years and seven months in the Trobriand Islands was not enough to produce a Trobriander. To 'live' a culture demands more than a knowledge of its events' system and institutions; it requires growing up with these events and being emotionally involved with cultural values and biases. (Uchendu 1965:9)

Beautifully worded. A quote I have always admired. Forty years later, however, my own fieldwork experience causes me to examine this assertion more critically. As I scrutinise the loaded argument, I find that I agree - with most of it. There can be no quarrel with the fact that the 'sympathetic foreign ethnologist', the 'culture-bearer' and others all have an 
important part to play in enriching the social science disciplines. But in focusing on Malinowski, and, perhaps, subconsciously on the archetypal (in other words, male and non-African) anthropologists of his time, my father inadvertently overlooks possible alternative positions.

One such alternative position can be found, I think, in the unique location of female culture-bearers in the Nigerian milieu. As an Obudu 'wife', I 'lived' the Obudu culture in spite of myself throughout my stay in Obudu, and continue to do so daily (even though I currently reside in Kenya). This does not only have to do with my knowledge of the culture's events' system and institutions. The duration of my stay in Obudu (or, indeed, the extent of my contact with my marital family) has little bearing on my status as an Obudu wife, which - in the eyes of my marital community - automatically makes me an Obudu culture-bearer. That the Ubang initially did not view me as such had more to do with my primary role in their community as a researcher than anything else. After a while, however, my status as an Obudu wife became an important part of my researcher identity. By the end of my fieldwork, when a reference was innocently made to the fact that I was an Igbo woman working on my doctoral degree, my brother-in-law corrected this 'faux pas', stating that I was an Obudu woman working on getting my doctorate. A wife's knowledge of her marital home's culture in indigenous Nigerian settings is necessarily gained, and becomes complete, over time.

As a wife, I am, of course, deeply and emotionally involved as I gradually learn about the culture of my husband and marital family-alongside learning about the specific local culture at my research site. I don't believe this diminishes my capacity as a culturebearing ethnographer. It presents a series of challenges that might be less acutely felt by other ethnographers. But it also presents a series of opportunities and openings. And, finally, it presents an alternative position that can contribute to ethnographic knowledge in an interesting way: who can describe the Obudu culture from a wife's perspective in the same way as an Obudu wife can? Clearly, the concept of emotional involvement discussed earlier in this paper can be extended to include my relationship to my husband and his family and culture. And, as noted above, this emotional involvement proved a help rather than a hindrance in my research encounter with the Ubang, in that it gave both me and my informants a certain amount of 'staying power', as well as a mutual interest in each other.

\section{A real anthropologist: to be or not to be(come)?}

One of the reviewers of my dissertation, a distinguished Igbo scholar, made a recommendation in a bid to help strengthen the work I had carried out in Ubang. Her useful advice was prefaced by the words: 'If you want your work to be like your father's...' (or something to that effect). In some ways, I suppose I did want to produce something comparable to his best-known work. Ironically, The Igbo of Southeast Nigeria was published even before my father obtained his doctoral degree in anthropology. Here I was, struggling to piece together a dissertation! An academic book, even at my level, seemed ridiculously ambitious to me. My sister has pointed out to me that 40 years ago, there were few culture-bearing ethnographers, which means that the sheer demand for a book such as The Igbo must have facilitated its publication during a relatively early 
period in my father's career. As we talked about this, I was not sure that I agreed with her reasoning, but at the same time I noted that her argument did make me feel somewhat better.

This raises another complex question tied to my researcher identity: why should trying to 'measure up' to my own father be a (subconscious) goal of mine? Some days, such a desire makes little sense to me. On other days, and at the risk of being labeled a navelgazer, I must confess that I adore the author of The Igbo. There is an inexplicably strong bond between us that not even my willful teenage years and inflexible young adult life have been able to destroy. To better illustrate the significance of our relationship, let me reveal that in accordance with the Igbo belief system, my father is an unapologetic believer in reincarnation (for rather convincing details regarding his beliefs about his own reincarnation, see Uchendu 1965:6) - and that he has always firmly believed that I am the reincarnation of his mother, whose life story he fondly devotes a large proportion of The Igbo's introduction to.

I am particularly proud of his portrayal of Igbo women in decades past, when utter female subordination in African settings was the anthropological mantra. Forty years ago, this was my father's opinion: 'The African woman regarded as the chattel of her husband, who has made a bridewealth payment on her account, is not an Igbo woman' (Uchendu 1965:87). A scholar ahead of his time, his insights are echoed in much of the Igbo gender theory that is so prevalent and influential today (see, for example, Amadiume 1987 and Nzegwu 2001).

On the other hand, there is room for the argument that he wrote primarily from a male perspective, and as a counter-balance to this, I would like to think that the uniqueness of my work lies in its devotion to the perspectives and experiences of women. I viewed the Ubang women as my collaborators - a term that exasperated my father as he read drafts of my dissertation chapters ('These are not your collaborators,' he would argue, 'these are your subjects!') - and I learned more from observing their daily lives, from their kind corrections, clarifications, and collaboration, that I ever could have in a classroom. As a result of their close involvement in helping me unravel Ubang culture and social meanings, I believe the Ubang community came to see me as a friend and a new Obudu wife, eager to learn - statuses I appreciated very much. This type of reflection on my own gendered position is also something that distinguishes my work from my father's. I recall that terms that I used liberally in my dissertation, such as 'positionality', were bereft of meaning, in my father's opinion. He would put a question mark (in addition to an exclamation mark, sometimes) next to this particular word each time it occurred in my numerous draft chapters.

The burning question remains: did I finally attain my father's status in the eyes of the Ubang community, or in the eyes of $\mathrm{Mr}$ Ochui, who was waiting for 'the real anthropologist' to arrive? After some months in the field, this question did not seem to matter, frankly - neither to them, nor to me. I would like to believe it became increasingly clear that my work and my father's work, though connected, are actually quite different. I arrived in Ubang wondering how to be an anthropologist. Being and working with the Ubang made me one. In the process, their perception of me changed, as did my perception of them, as well as my perception of myself. But the one thing that has not changed, the one thing I still know for sure, is that I am my father's daughter. 


\section{References}

Abu-Lughod, L. 1987. Veiled Sentiments: Honour and Poetry in a Bedouin Society. Cairo: American University Press.

Achebe, N. 2002. Nwando Achebe-daughter, wife, and guest-a researcher at the crossroads. (Getting to the source). Journal of Women's History 14(3), 9-31.

Amadiume, I. 1987. Male Daughters, Female Husbands: Gender and Sex in an African Society. London: Zed Books.

Clifford, J. and G. Marcus (eds). 1986. Writing Culture: The Poetics and Politics of Ethnography. Berkeley: University of California Press.

Elliston, D. 2005. Critical reflexivity and sexuality studies in anthropology: siting sexuality in research, theory, ethnography, and pedagogy. Reviews in Anthropology 34, 21-47.

Newton, E. 1993. Cherry Grove, Fire Island: Sixty Years in America's First Gay and Lesbian Town. Boston: Beacon Press.

Nzegwu, N. 2001. Gender equality in a dual-sex system: the case of Onitsha. Jenda: A Journal of Culture and African Women Studies 1(1) (http://www.jendajournal.com/voll.1/nzegwu.pdf).

Osuji, F.N.C. 1995. Foreword. In Ezi Na Ulo: The Extended Family in Igbo Civilization. The 1995 Ahiajoku lecture by V.C. Uchendu. Owerri-Imo State, Nigeria (http://ahiajoku.igbonet.com/1995/).

Uchendu, V.C. 1965. The Igbo of Southeast Nigeria. New York: Holt, Rinehart and Winston.

\section{Acknowledgements}

I would like to acknowledge the input of three anonymous reviewers whose comments were critical to the development of this paper. The paper is dedicated to the memory of my father, HRH Eze (Prof.) V.C. Uchendu, whose untimely death occurred after the final editing of this paper, on December 7, 2006.

\section{About the author}

Chi-Chi Undie is a 2003 graduate of an interdisciplinary doctoral program in Language, Literacy and Culture at the University of Maryland, Baltimore County in the United States. Her dissertation is an ethnography of the Ubang people, entitled Equal Encounters: Gender, Language and Power in the Ubang Community of Obudu, Nigeria. She is currently an Associate Research Scientist at the African Population and Health Research Center in Nairobi, Kenya, and can be reached at cundie@aphrc.org or chichiundie@gmail.com. 